\title{
MICROSTRUCTURE, WEAR RESISTANCE AND MICROHARDNESS OF W-PARTICLE-STRENGTHENED Ti6Al4V COMPOSITE PRODUCED WITH LASER METAL DEPOSITION
}

\author{
MIKROSTRUKTURA, ODPORNOST PROTI OBRABI IN \\ MIKROTRDOTA LASERSKO IZDELANEGA, Z W-DELCI \\ OJAČANEGA Ti6Al4V KOMPOZITA
}

\author{
Ndivhuwo Ndou, ${ }^{1,2}$ Esther Akinlabi ${ }^{2}$ \\ ${ }^{1}$ University of South Africa, Department of Mechanical and Industrial Engineering, Florida Johannesburg 1710, South Africa \\ ${ }^{2}$ University of Johannesburg, Department of Mechanical Engineering Science, Kingsway Campus, Johannesburg 2006, South Africa \\ nndou@unisa.ac.za
}

Prejem rokopisa - received: 2017-06-19; sprejem za objavo - accepted for publication: 2017-11-03

The objective of this work was to investigate a Ti6Al4V/W composite coated by means of the laser-power process. The microhardness profile, microstructure and wear properties of $\mathrm{W}$ particles, produced with laser metal deposition (LMD), were explored. Different power-flow rates were used in the study, ranging from $800 \mathrm{~kW}$ to $1400 \mathrm{~kW}$, with the other parameters kept constant. The results showed that the LMD process allows the production of a suitable bond between the substrate zone and the clad zone. It was found that LMD has a direct effect on the microhardness and microstructures. The microhardness and wear resistance of the deposited material produced with LMD were higher than those of the Ti6Al4V substrate. The wear result obtained at a laser power of $1000 \mathrm{~W}$ revealed better wear resistance than that of the composite coating obtained at $900 \mathrm{~W}$ or $1200 \mathrm{~W}$.

Keywords: microhardness, microstructure, surface modification, wear resistance, wear volume

Predmet tega prispevka je opis raziskave kompozita Ti6Al4V/W, pri katerem je bil W vnešen v substrat z laserskim postopkom. Avtorji raziskave so določili profil mikrotrdote, mikrostrukturo in odpornost proti obrabi plasti W delcev, ki so bili vnešeni s postopkom laserske depozicije kovine (LMD, angl.: Laser Metal Deposition). V študiji so uporabili različno moč laserja v območju med $800 \mathrm{~kW}$ in $1400 \mathrm{~kW}$, pri čemer so ostale parametre obdržali konstantne. Rezultati kažejo, da je z LMD procesom možno izdelati primerno vez med Ti6Al4V substratom (podlago) in nanešenim materialom (W). Avtorji so ugotovili, da LMD proces vpliva direktno na mikrotrdoto in mikrostrukturo. Mikrotrdota in odpornost proti obrabi plasti, nastali z LMD nanešenega materiala, sta višji, kot jo ima osnovni Ti6Al4V substrat. Odpornost proti obrabi kompozitne plasti, izdelane z močjo laserja $1000 \mathrm{~W}$, je boljša kot so jo avtorji raziskave dosegli z močmi laserja $900 \mathrm{~W}$ in $1200 \mathrm{~W}$.

Ključne besede: mikrotrdota, mikrostruktura, površinska modifikacija, odpornost proti obrabi, obseg obrabe

\section{INTRODUCTION}

In view of its thinness, the prevalent quality at high temperatures, and good corrosion resistance, Ti6Al4V is indispensable in the development of most parts utilised in aerospace. ${ }^{1,2}$ Because of the good chemical activity and low thermal conductivity, titanium alloys are viewed as hard materials. ${ }^{3,4} \mathrm{~A}$ chemical reaction of titanium at a high temperature brings about the creation of a strong layer, prompting reduced tool life. ${ }^{5}$ Parts for the aviation industry are considered to be hard to machine owing to their mechanical properties.

Tungsten powder is a vital material due to its wear resistance, high hardness and excellent quality. However, due to its composition, $\mathrm{W}$ cannot be machined effectively by means of traditional procedures. ${ }^{6}$ Instead, it can be machined using non-conventional methods such as laser metal deposition (LMD). Laser surface modification is utilised to improve the surface of a workpiece because it increases the life of the workpiece while reducing the manufacturing cost, ${ }^{7}$ and it guarantees the surface hard- ness. ${ }^{8}$ Many surface modifications have been utilised to enhance the wear properties of titanium compounds, with or without success; these include laser and plasma surface treatment, ${ }^{9}$ sol-gel processing ${ }^{10,11}$ and nitriding. ${ }^{12}$ Surface modification using lasers seems, by all accounts, to be of interest in the light of the fact that lasers allow high coherence and accuracy in a specific range without damaging any part of the surface. ${ }^{13}$ LMD processes such as laser melting and laser cladding can produce coatings with better metallurgical bonding.

Titanium alloys are essential for the developments within the aeroplane industry and vehicle engines. ${ }^{14}$ Close net-framed titanium fragments can, without a doubt, be created at a significantly lower cost. ${ }^{15-17}$

Previously, various technologies for making metalmatrix composites (MMC) of various Ti mixes were utilised. ${ }^{18-22}$ LMD is viewed as a reasonable technology for this purpose. ${ }^{23,24}$ The LMD process entails the use of the laser power that melts the top layer of a metal substrate. Complex parts are produced by means of LMD at 
a significantly lower cost than by means of conventional methods. ${ }^{25}$

Lately, it has been demonstrated that tungsten particles can be used in a titanium matrix, creating a Ti-W coating of exceptional quality and good strength. ${ }^{26}$

In the current study, investigations were conducted to determine the effect of the laser power on the wear resistance, microhardness and microstructure of the produced Ti6Al4V/W composites using the LMD process.

\section{EXPERIMENTAL METHODS}

\subsection{Equipment and sample preparation}

Prior to the deposition procedure, the substrate was cleaned using a sandblast machine with the specific goal to remove the undesirable material to provide for sufficient metallographic joining. The surface of the material was cleaned with acetone to enhance the laser-control retention. The deposition of Ti6Al4V/W particles was performed at the National Laser Centre of the Council for Scientific and Industrial Research (CSIR) in Pretoria, South Africa, using a machine with a maximum power of $4400 \mathrm{~W}$. LMD was carried out using the laser technology employing a Kuka robot. The powder feeder was loaded with Ti6Al4V and $\mathrm{W}$ powders at a flow rate specifically relative to the rotational speed. It is better to utilise isolated dual hoppers than pre-mixed powders, as pre-blended powders are not of a uniform density. ${ }^{25}$ Chambers were loaded with argon gas, which is utilised to prevent oxygen contamination on a deposited sample composite. Argon gas was used to prevent the deposited samples from oxidising during the procedure, to control the gas, to make the powder and to make the dissolved metal flow in the anticipated direction.

The powder particles were injected into the dissolving pool through a coaxial nozzles, while a powerful laser beam dissolved the deposited material over the substrate or base metal (Figure 1).

\subsection{Experimental procedure}

A $10-\mathrm{mm}$ Ti6Al4V sample plate with dimensions of $(200 \times 100 \times 10) \mathrm{mm}$ was utilised as the substrate.

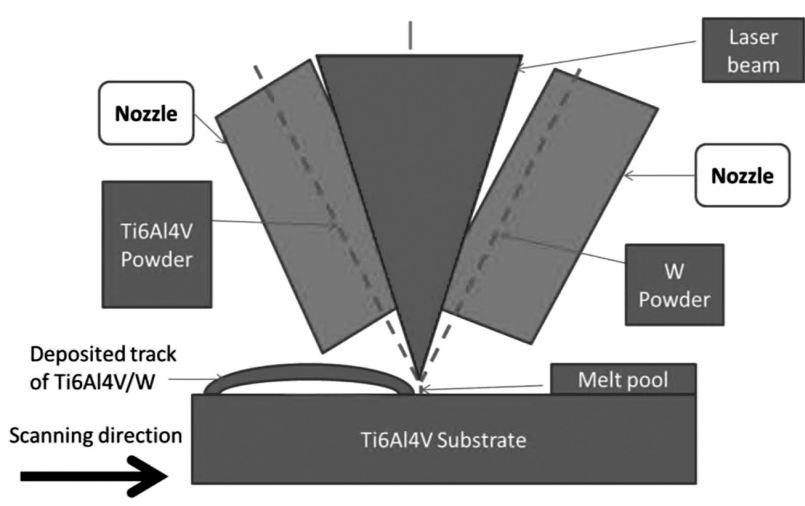

Figure 1: Experiment set-up

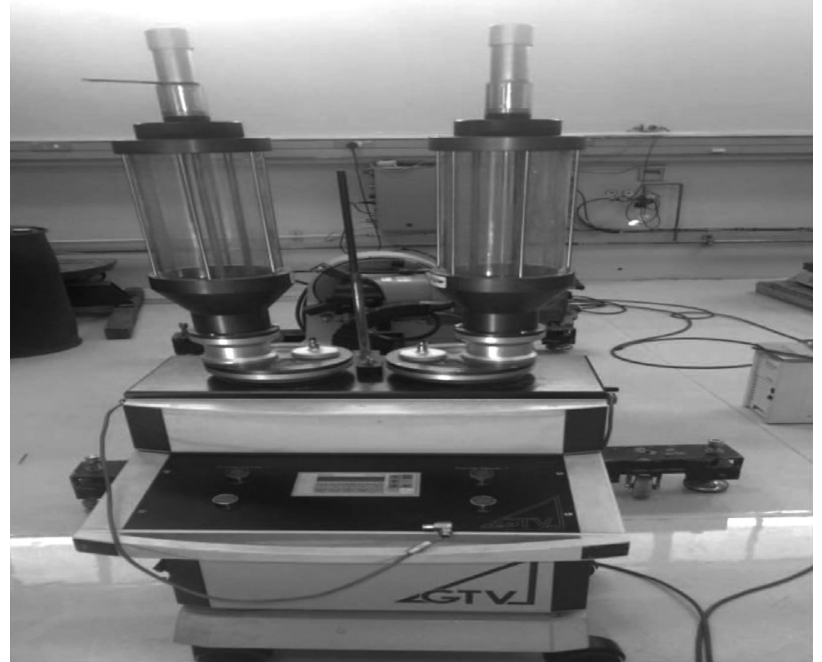

Figure 2: Double feeder of $\mathrm{W}$ and Ti6Al4V powders

Dual-feeder hoppers were utilised to permit concurrent cladding of the powders. The laser-beam diameter was set at $2 \mathrm{~mm}$ and the beam space was kept constant at $2 \mathrm{~mm}$ throughout the process. After the deposition procedure, all the coated samples were cleaned to remove the unwanted material. Figure 2 illustrates two separate hoppers, each containing a different powder. The powder feeder was set according to the predetermined ratio. Table 1 depicts the process parameters used in this study.

Coated samples were produced utilising laser metal deposition and the produced samples were designated A1 to A5. The samples were mounted, with polyfast resin, utilising a hot mounting press.

Table 1: Process parameters

\begin{tabular}{|c|c|c|c|c|c|c|}
\hline \multirow{2}{*}{$\begin{array}{c}\text { Speci- } \\
\text { men }\end{array}$} & \multirow{2}{*}{$\begin{array}{c}\text { Power } \\
(\mathrm{kW})\end{array}$} & $\begin{array}{c}\text { Scanning } \\
\text { speed } \\
(\mathrm{m} / \mathrm{min})\end{array}$ & $\begin{array}{c}\text { Powder-flow rate } \\
\left(\mathrm{min}^{-1}\right)\end{array}$ & \multicolumn{2}{|c|}{ Gas-flow rate } \\
\cline { 4 - 7 } & & & Ti6Al4V & $\mathrm{W}$ & Ti6Al4V & W \\
\hline A1 & 0.8 & 0.7 & 9.5 & 0.5 & 1.5 & 3 \\
\hline A2 & 0.9 & 0.7 & 9.6 & 0.6 & 1.5 & 3 \\
\hline A3 & 1 & 0.7 & 9.7 & 0.7 & 1.5 & 3 \\
\hline A4 & 1.1 & 0.7 & 9.8 & 0.8 & 1.5 & 3 \\
\hline A5 & 1.2 & 0.7 & 9.9 & 0.9 & 1.5 & 3 \\
\hline
\end{tabular}

\subsection{Microstructure}

The coated samples were sectioned and mounted, with polyfast resin, using a Lecco PR25 mounting-press machine. After the mounting, all the samples were grinded to reveal the coated surface. They were then polished with 320 bonded papers using MD CHEM with an OP-S suspension. After the polishing process, they were cleaned with running water and acetone. The subscript was prepared with $100 \mathrm{~mL} \mathrm{H}_{2} \mathrm{O}, 3 \mathrm{~mL} \mathrm{HF}, 4 \mathrm{~mL}$ $\mathrm{HNO}_{3}$ and $\left(30 \% \mathrm{H}_{2} \mathrm{O}_{2}, 70 \% \mathrm{H}_{2} \mathrm{O}\right)$. The polished specimens were first etched for $11 \mathrm{~s}$ to $16 \mathrm{~s}$ according to the metallographic procedure. A microstructural analysis was conducted using optical microscopy. Additionally, investigations for characterising the samples were done 
by means of high-resolution images of SEM, and EDS was used for the chemical analysis. The samples used for analysing the microstructure were prepared metallurgically according to the E3-11 ASTM standard. ${ }^{27}$

\subsection{Hardness}

The microhardness profile was determined using the Vickers microhardness test. The hardness distribution was measured according to the E384-11El ASTM standard. ${ }^{28}$ The indentation load used was $500 \mathrm{~g}$, with a dwell time of $12 \mathrm{~s}$, and the space among the indentations was kept constant at $10 \mu \mathrm{m}$.

\subsection{Wear-resistance testing}

Dry-sliding-wear testing of the Ti6Al4V/W coating was carried out by means of a CERT tribometer. The samples, with dimensions of $(200 \times 100 \times 100) \mathrm{mm}$,
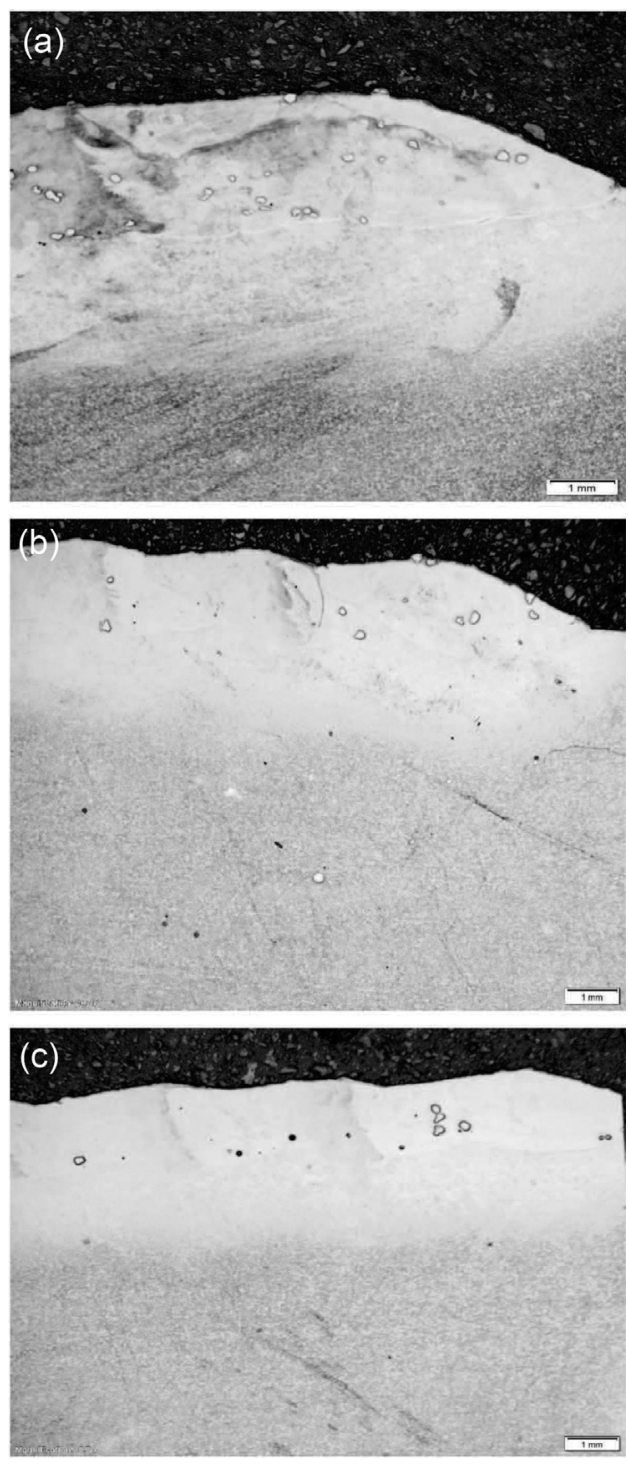

Figure 3: Etched SEM micrographs showing the coatings deposited at various laser powers: a) $900 \mathrm{~W}$, b) $1000 \mathrm{~W}$ and c) $1200 \mathrm{~W}$ were pressed under a load of $25 \mathrm{~N}$. The wear resistance of the Ti6Al4V/W coating was evaluated for a sliding distance of up to $2000 \mathrm{~m}$ and a reciprocation frequency of $20 \mathrm{~Hz}$. Wear-scar images were obtained using highresolution images of SEM. The wear volume was obtained by calculating the track area of the deposited coating. Following the G133-05(2010) ASTM standard ${ }^{29}$ all the samples were tested on a dry-sliding-wear tester.

\section{RESULTS}

\subsection{Microstructure}

The study was carried out on deposited Ti6Al4V and W. Figures 3a to $\mathbf{3 c}$ show etched cross-sections on scanning-electron-microscopy (SEM) micrographs of the Ti6Al4V/W coatings deposited by means of laser metal deposition at laser powers of $(900,1000$ and 1200) W.

At the laser power of $1200 \mathrm{~W}$, the microstructure showed a degree of porosity. It can be attributed to the extended solubility of air in the melt pool with the increased heat input. ${ }^{25} \mathrm{~W}$-powder particles were uniformly distributed at the laser powers of $900 \mathrm{~W}$ and $1000 \mathrm{~W}$. W particles at the laser power of $1200 \mathrm{~W}$ were evenly distributed, with little porosity.

Figure 4 shows SEM micrographs of Ti6414V/W coated with a laser power of 1000 W. Figure 4a illustrates three zones, namely, the top surface of the coating, the layer between the clad zone and the substrate, and the heat-affected zone. Good bonding between the clad zone and the substrate is also illustrated in Figure 4a. Figure 4b shows Ti6Al4V needles forming a basketweave pattern. Figure $\mathbf{4 c}$ shows the heat-affected zone and the microstructure of the deposited coating. At the joining boundary line, the coating is characterised by a
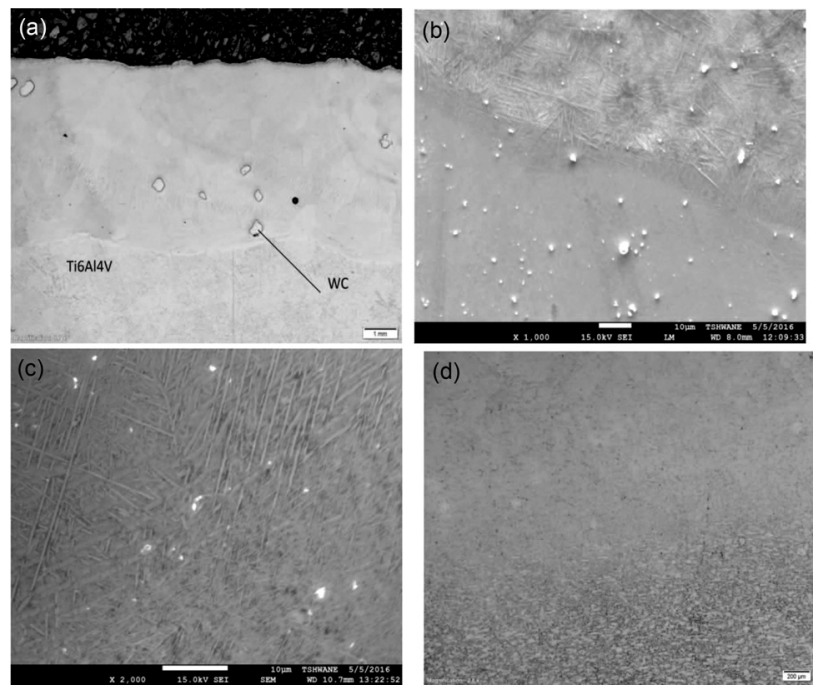

Figure 4: SEM images of etched microstructures: a) direct laser melting at $1000 \mathrm{~W}, \mathrm{~b}$ ) cross-section of top layers, c) cross-section of deposited and heat-affected zones and d) cross-section of the heat-affected zone and Ti6Al4V substrate 
thin strip that is completely covered with $\mathrm{W}$ particles. Figure 4d shows the microstructure of the heat-affected zone and the substrate bonding. The Ti6Al4V/W coatings produced at the laser power of $1000 \mathrm{~W}$ were achieved with little dilution. The bonding between the clad layer and the substrate is shown in Figure $\mathbf{4 d}$, in which it is possible to identify where the coating and substrate merge. It can be concluded that the coating on the clad layer was strong, with less dilution. The W coatings on the top surface of the coating reinforce the material.

\subsection{Microhardness}

The coatings were indented from their upper surface through to the substrate in accordance with ASTME E1184. The increment in the microhardness was observed on five samples with deposited coatings. Figure 5 shows the hardness profiles for various laser powers. The hardness of the composite coating increased with the increasing laser power. Be that as it may, the microhardness measurement of the coating deposited at $1100 \mathrm{~W}$ (N4) showed the lowest hardness. Figure 5 shows the microhardness profiles of the coatings deposited at the laser powers of 800-1200 W.

Figure 6 shows the laser power of $1000 \mathrm{~W}$ with the highest hardness value of $719 \mathrm{HV}$. The hardness of the substrate used was $350 \mathrm{HV}$. The hardness value for the deposition zone (top layer) was 719 HV. The microhardness measurement was conducted on all the samples, on the cross-sections of the composites. Figure 6 shows the highest hardness value of $719 \mathrm{HV}$. The highest value can be contributed to the high level of martensite and the generation of the Widmanstatten pattern.

These results show that the coating of $\mathrm{W}$ particles improves the hardness of the material. They also show that the coating at the interface between the HAZ and the substrate was hard. The hardness increased in compari-

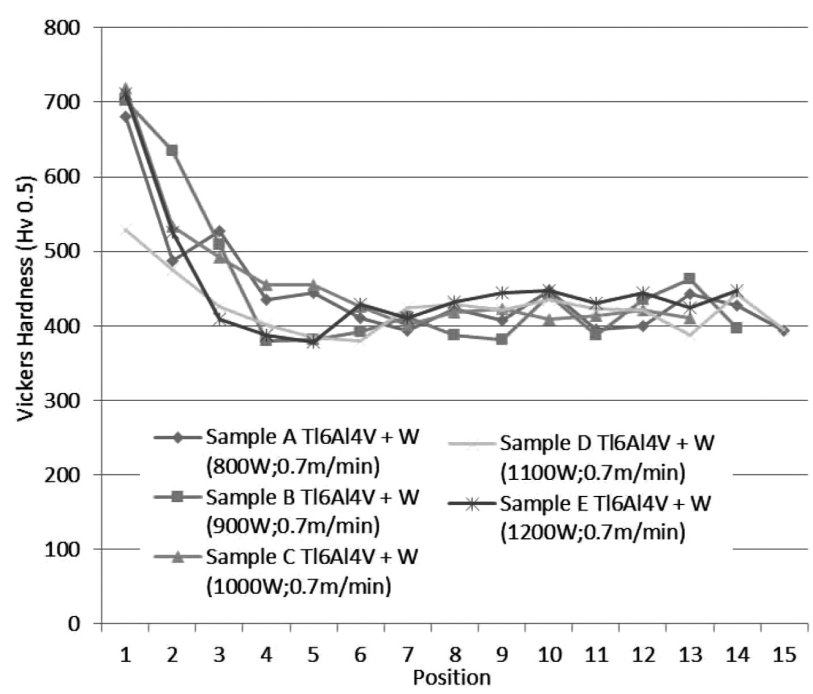

Figure 5: Hardness profiles of the composite coatings

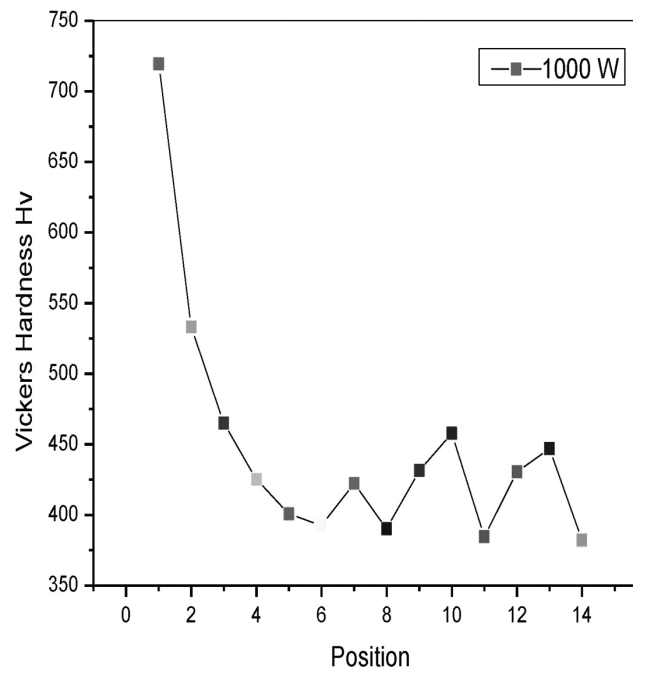

Figure 6: Hardness profile for the deposition achieved with $1000 \mathrm{~W}$

son to that of the substrate. This value is acceptable, showing good bonding between the coating and the substrate. No splits or cracks formed during the indentation procedure, which means that the coating is solid.

\subsection{Wear-resistance testing}

Wear tests were performed on all the samples. Figure 7a shows the SEM microstructure of the wear track formed by a sliding motion on Ti6Al4V/W. Figure $7 \mathbf{b}$ is a higher-resolution micrograph of the wear track. The wear-worn surface displayed numerous grooves and debris arising from the detached material. The wear observed on the Ti6Al4V/W composite coating entailed abrasion and a blend of adhesion and plastic deformation. The abrasion takes place early on, as the tungstencarbide ball interacts with the surface of the substrate, leading to the rubbing action of the two surfaces. Adhesion occurs when the rubbing of the two surfaces proceeds with no oil lubrication, causing strong adhesion. ${ }^{30}$ Strong adhesion creates high temperature and results in the development of debris, which increases the wear action. As the temperature continues to increase, the wear debris solidifies and the sliding activity continues.

The effect of the load was observed during the sliding test. The titanium hardness was lower than that of tungsten, and serious wear occurred under the increasing load, with a deep groove being formed. All the coatings were deposited at various laser powers of $(900,1000$ and 1200) W. The coating deposited at the laser power of $900 \mathrm{~W}$ showed an increment in the wear resistance. The coating deposited at the laser power of $1000 \mathrm{~W}$ demonstrated a higher wear rate than that deposited at the laser power of $900 \mathrm{~W}$. The further increase in the laser power to $1200 \mathrm{~W}$ gave rise to a yet higher wear rate. This effect of increasing the laser power can be attributed to the distribution of the tungsten powder. The outcome demonstrates that the samples were exposed to a sliding 


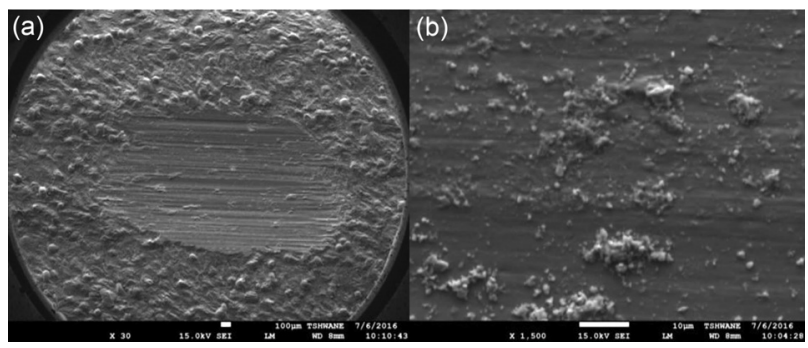

Figure 7: Etched microstructure and a wear track visible with SEM: a) $30 \times$ magnification and b) $1500 \times$ magnification

action, which caused adhesive wear. Moreover, a number of grooves and scars were seen on the worn surfaces of the samples. The lower laser power resulted in less unmelted carbide (UMC). With less UMC, the wear resistance of the material is poor owing to the reduced support effect of the Ti6Al4V/W powder. ${ }^{30}$

The coatings deposited at the laser powers of 800-1200 W showed a lower wear volume contrasted to the Ti6Al4V substrate and the coatings deposited at a laser power of $1000 \mathrm{~W}$. The wear resistance increased due to the LMD process can be attributed to the distribution of the $\mathrm{W}$ powder in the coatings.

Table 2 presents the wear volume at various laser powers.

Table 2: Wear volume at various laser powers

\begin{tabular}{|l|c|}
\hline \multicolumn{1}{|c|}{ Samples } & $\begin{array}{c}\text { Wear } \\
\text { volume } \\
(\mathrm{mm})\end{array}$ \\
\hline Laser power $0.8 \mathrm{~kW}$ and scan speed of $0.7 \mathrm{~m} / \mathrm{min}$ & 0.144 \\
\hline Laser power $0.9 \mathrm{~kW}$ and scan speed of $0.7 \mathrm{~m} / \mathrm{min}$ & 0.0171 \\
\hline Laser power $1.0 \mathrm{~kW}$ and scan speed of $0.7 \mathrm{~m} / \mathrm{min}$ & 0.076 \\
\hline Laser power $1.1 \mathrm{~kW}$ and scan speed of $0.7 \mathrm{~m} / \mathrm{min}$ & 0.089 \\
\hline Laser power $1.2 \mathrm{~kW}$ and scan speed of $0.7 \mathrm{~m} / \mathrm{min}$ & 0.124 \\
\hline Substrate material & 0.314 \\
\hline
\end{tabular}

The laser power of $1000 \mathrm{~W}$ was observed to result in the lowest percentage of the wear volume of $8 \%$. The laser power of $900 \mathrm{~W}$ gave rise to a high wear-volume percentage of $19 \%$. The breadth and length of the wear track at the laser power of $900 \mathrm{~W}$ were greater than those of all the other samples except the substrate. Table 2 demonstrates that the sliding-wear rate of the coating samples deposited at various laser powers is lower than that of the substrate. The substrate shows the highest wear volume of all the samples.

\section{CONCLUSIONS}

This article reports on a $\mathrm{W}$ reinforcement of the Ti6Al4V alloy achieved by means of LDM. Different laser powers were used, affecting the microstructure, and the LMD process ensured the microhardness of the Ti6414V/W coatings. The hardness, microstructure, chemical analysis and wear behaviour of the coated material were investigated. The findings of the study are as follows:
- The LMD process is appropriate for achieving suitable bonding between the substrate and the cladding area.

- The coated sample deposited at a laser power of $1000 \mathrm{~W}$ exhibits the maximum microhardness value of $719 \mathrm{HV}$.

- The composite coating deposited at laser powers of 1000 and $900 \mathrm{~W}$ revealed no porosity or cracks in the microstructure of most of the produced samples. However, porosity was observed in the microstructure obtained at a laser power of $1200 \mathrm{~W}$.

- Tungsten particles enhanced the surface hardness of the coated alloy, and the composite coated at the laser power of $1000 \mathrm{~W}$ showed a higher wear resistance than the coated samples produced at the laser powers of 900 and $1200 \mathrm{~W}$.

- The strength of the Ti6Al4V/W composites after the LMD process was much higher than that of the Ti6A14V alloy. The wear resistance of the Ti6Al4V/W composites was much higher than that of the Ti6Al4V alloy.

\section{Acknowledgments}

The acknowledgement goes to the staff members of the Tshwane University of Technology who assisted with the laboratory equipment.

\section{REFERENCES}

${ }^{1}$ C. Leyens, M. Peters, Titanium and titanium alloys, Wiley Online Library, 2003

${ }^{2}$ E. Zugwu, J. Bonney, E. Y. Yaman, An overview of the machinability of aeroengine alloys, Journal of Materials Processing Technology, 134 (2003), 233-253

${ }^{3}$ M. Rahman, Z. G. Wang, Y. S. Wong, A review on high-speed machining of titanium alloys, JSME International Journal Series $C$, 49 (2006), 11-20

${ }^{4}$ K. G. Budinski, Tribological properties of titanium alloys, Wear, 151 (1991), 203-217

${ }^{5}$ T. Matikas, P. Nicolaou, Prediction of contact temperature distribution during fretting fatigue in titanium alloys, Tribology Transactions, 52 (2009), 346-353

${ }^{6}$ I. Puertas, C. J. Luis, L. Alvarez, Analysis of the influence of EDM parameters on surface quality: MRR and EW of WC-Co, Journal of Materials Processing Technology, 153-154 (2004), 1026-1032

${ }^{7}$ P. Janmanee, A. Muttamara, Surface modification of tungsten carbide by electrical discharge coating (EDC) using a titanium powder suspension, Applied Surface Science, 258 (2012), 7255-7265

${ }^{8}$ M. B. Frish, P. E. Nebolsine, A. N. PirrI, Method for bonding using laser induced heat and pressure, Google Patents, 1987

${ }^{9}$ G. Cassar, S. Banfield, J. C. A. B. Wilson, J. Housden, S. A. Matthew, A. Leyland, Micro-abrasion wear testing of triode plasma diffusion and duplex treated Ti-6Al-4V alloy, Wear, 274-275 (2012), 377-387

${ }^{10}$ Y. P. Choudhur, D. C. Agrawal, Sol-gel derived hydroxyapatite coatings on titanium substrates, Surface and Coatings Technology, 206 (2011), 360-365

${ }^{11}$ W. Zhang, C. Wang, W. Liu, Characterization and tribological investigation of sol-gel ceramic films on Ti-6Al-4V, Wear, 260 (2006), 379-386 


\section{N. NDOU, E. AKINLABI: MICROSTRUCTURE, WEAR RESISTANCE AND MICROHARDNESS OF W-PARTICLE- ...}

${ }^{12}$ K. C. Chen, G. J. Jaung, D.c. diode ion nitriding behavior of titanium and Ti-6AI-4V, Thin Solid Films, 303 (1997), 226-231

${ }^{13}$ Y. Tian, C. Chen, S. LI, Q. Huo, Research progress on laser surface modification of titanium alloys, Applied Surface Science, 242 (2005), 177-184

${ }^{14} \mathrm{H}$. Sibum, Titanium and titanium alloys - from raw material to semi-finished products, Advanced Engineering Materials, 5 (2003), 393-398

${ }^{15}$ R. Vilar, Laser cladding, Journal of Laser Applications, 11 (1999), 64-79

${ }^{16}$ D. Boisselier, S. Sankaré, Influence of powder characteristics in laser direct metal deposition of SS316L for metallic parts manufacturing, Physics Procedia, 39 (2012), 455-463

${ }^{17}$ J. Koch, J. Mazumder, Rapid prototyping by laser cladding, Laser Materials Processing, 556 (1994)

${ }^{18}$ B. Kooi, Y. Pei, J. T. M. De Hosson, The evolution of microstructure in a laser clad TiB-Ti composite coating, Acta Materialia, 51 (2003), 831-845

${ }^{19}$ Y. J. Kim, H. Chung, S. J. L. Kang, Processing and mechanical properties of Ti-6Al-4V/TiC in situ composite fabricated by gas-solid reaction, Materials Science and Engineering, 333 (2002), 343-350

${ }^{20}$ R. Banerjee, A. Genc, D. Hill, P. Collins, H. Fraser, Nanoscale TiB precipitates in laser deposited Ti-matrix composites, Scripta Materialia, 53 (2005), 1433-1437

${ }^{21} \mathrm{~S}$. Mridha, T. Baker, Metal matrix composite layers formed by laser processing of commercial purity $\mathrm{Ti}-\mathrm{SiCp}$ in nitrogen environment, Materials Science and Technology, 12 (1996), 595-602
${ }^{22} \mathrm{~S}$. Mridha, T. Baker, Incorporation of $3 \mu \mathrm{m} \mathrm{SiC} \mathrm{p}$ into titanium surfaces using a $2.8 \mathrm{~kW}$ laser beam of 186 and $373 \mathrm{MJ} \mathrm{m}^{-2}$ energy densities in a nitrogen environment, Journal of Materials Processing Technology, 185 (2007), 38-45

${ }^{23}$ E. Toyserkani, A. Khajepour, A mechatronics approach to laser powder deposition process, Mechatronics, 16 (2006), 631-641

${ }^{24}$ J. Scott, N. Gupta, C. Weber, S. Newsome, T. Wohlers, T. Caffrey, Additive manufacturing: status and opportunities, Science and Technology Policy Institute, Washington, DC, (2012), 1-29

${ }^{25}$ R. M. Mahamood, E. T. AkinlabI, M. Shukla, S. Pityana, Effect of laser power on material efficiency, layer height and width of laser metal deposited Ti6Al4V, 2012

${ }^{26} \mathrm{H}$. Choe, Effect of tungsten dissolution on the mechanical properties of Ti-W composites, J Alloys Compd, 390 (2005), 62-66

${ }^{27}$ Standard, A, E3-11: Standard Guide for Preparation of Metallographic Specimens, ASTM International, West Conshohocken, PA (2012)

${ }^{28}$ Standard, A, E384-11E1: Standard test method for Knoop and Vickers hardness of materials, ASTM International, West Conshohocken, PA (2007), doi:10.1520/E0384-11E01

${ }^{29}$ Standard Test Method for Linearly Reciprocating Ball-on-Flat Sliding Wear, ASTMG133-05 (2005)

${ }^{30}$ R. M. Mahamood, E. T. Akinlabi, M. Shukla, S. Pityana, Scanning velocity influence on microstructure, microhardness and wear resistance performance of laser deposited Ti6Al4V/TiC composite, Materials and Design, 50 (2013), 656-666 